\title{
AMERICAN ADMINISTRATIVE LAW UNDER SIEGE: IS GERMANY A MODEL?
}

\section{Susan Rose-Ackerman*}

The American regulatory state is under attack. Economists criticize the irrationality of substantive policies. ${ }^{1}$ Political scientists attack administrative policymaking and implementation as cumbersome, disjointed, and adversarial. ${ }^{2}$ Law professors argue that the administrative process is legalistic, time-consuming, and ineffective. ${ }^{3}$ Commentators, including some now on the federal bench, argue that judicial scrutiny has induced agencies to make fewer rules and to seek less accountable ways of making policy. ${ }^{4}$ They urge the courts to defer more frequently to agency decisions. ${ }^{5}$ The criticisms have built to such a crescendo that the system seems in crisis.

But appearances are deceiving. Although reform is needed, many critics have overstated their case. The most popular reform proposals would destroy much of value in the American system.

Modern democracies need to strike a balance between popular control and expertise, at the same time as they restrain the influence of narrow, organized groups. Bureaucratic policymaking is an inevitable consequence of the complexity of problems facing the modern state. It cannot be performed by the legislature or the judiciary, but it needs to be monitored both by these formal organs of state power

* Henry R. Luce Professor of Jurisprudence (Law and Political Science), Yale University. B.A. 1964, Wellesley College; Ph.D. (economics) 1970, Yale University.

1 For a general critique, see W. Kip Viscusi, Health and Safety Regulation, in AMERICAN ECONOMIC POLICY IN THE I980S, at 453, 50I-02 (Martin Feldstein ed., I994), and, on environmental policy, the essays collected in Public Policies for Environmental Protection (Paul R. Portney ed., I990).

2 See, e.g., John M. Mendeloff, The Dilemma of Toxic Substance Regulation: How OverRegulation CaUSES UNDERREgUlation at OSHA I-I7 (I988) (arguing that OSHA regulates too few substances but imposes overly strict standards for those that it does regulate); John Mendeloff, Regulating Safety: an Economic and Political Analysis of OcCupational SAFETy aNd Healith Policy i45-50 (1979) (recommending the use of cost-benefit analyses in setting health and safety standards).

3 See, e.g., Jerry Mashaw, Improving the Environment of Agency Rulemaking: An Essay on Management, Games, and Accountability, 57 LAW \& ConTEMP. ProBs. (forthcoming Winter 1994) (arguing for an end to preenforcement review); Rosemary O'Leary, The Impact of Federal Court Decisions on the Policies and Administration of the U.S. Environmental Protection Agency, 4I ADMIN. L. REV. 549, 563-67 (I989) (arguing that judicial review has led the EPA to devote excessive resources to litigation).

4 See, e.g., JerRy L. Mashaw \& David L. Harfst, The Struggle for Auto Safety passim (rggo) (arguing that judicial review has impelled the NHTSA from rulemaking to product recalls); Antonin Scalia, Back to Basics: Making Law Without Making Rules, REgulation, July-Aug. I98I, at 25, 27 (arguing that recent developments, including exacting judicial review, have given agencies reason to reconsider policymaking by adjudication).

5 See, e.g., R. Shep Melnick, Regulation and the Courts: The Case of the Clean Arr ACT passim (1983) (arguing that judges should defer more frequently to the EPA). 
and by ordinary citizens. ${ }^{6}$ Although the administrative process must be under bureaucratic control, both judicial review and administrative attention to outside individuals and groups are necessary to ensure democratic legitimacy and competence.

My own view of the proper judicial role draws on two recent developments in social science. First, social choice theory demonstrates the fundamental difficulties of making consistent policy choices under democratic conditions. It teaches that democracy may produce illogical and inconsistent results. ${ }^{7}$ Rational choice models of politics counsel careful monitoring of the representative system because of the weak incentives for citizens to become informed about political choices. Second, policy analysis recommends the systematic weighing of costs and benefits as a means of improving executive-branch policymaking. ${ }^{8}$

My joint commitments to expertise and to democracy lead me to conclude that delegation is justified, but only if administrative procedures are open and accountable. The rational choice literature suggests that the legislative process requires monitoring. As a consequence, I have argued elsewhere for a two-fold judicial role in reviewing both the activities of federal regulatory agencies and the actions of Congress. ${ }^{9}$ First, courts should impose a background costbenefit norm when agencies implement laws that seek to improve the efficiency of the economy. ${ }^{10}$ Such a background norm would make it more difficult for Congress to pass laws that favor narrow interests unless Congress clearly states its intention to do so in the text of the statute. ${ }^{11}$ Second, courts should acknowledge what has always been obvious to political scientists and Washington observers - that Congress often takes actions that do not have majority support and then disguises what it has done. The courts should take some modest steps to improve the transparency of the legislative process. They should review statutes for harmony between means and ends, review appro-

${ }^{6}$ See Christopher F. Edley, Jr., Administrative Law: Rethinking Judicial ConTROL OF BUREAUCRACY 13-95 (1990) (examining the relationship between politics, law, and expertise and urging reform to promote sound government and more effective judicial review); Susan Rose-Ackerman, Rethinking the Progressive Agenda: The Reform of the AMERican Regulatory State 33-42 (1992).

i See Dennis C. Mueller, Public Choice II, at 2-6 (1989). The classic proof of this result appears in Kenneth J. ARrow, Soctal Choice and Individual Values 9-2 i (2d ed. I963).

${ }^{8}$ See Rose-Ackerman, supra note 6, at i4-19; Edith Stokey \& Richard Zeckhauser, A PRIMER For Policy ANALYSis r $34-58$ (1978).

${ }^{9}$ See Rose-ACKeRMAN, supra note 6, at 33-79.

${ }^{10}$ See id. at 33-42.

11 The D.C. Circuit recently supported the use of such a norm under the Occupational Safety and Health Act, 29 U.S.C. $\S 652(8)$ (1988). See International Union, UAW v. OSHA, 938 F.2d I310, I318-2I (D.C. Cir. I991). 
priations for consistency with statutory purposes, and forbid the inclusion of substantive provisions in appropriations acts. ${ }^{12}$ The aim of these proposals is to improve the operation of Congress, but they will also ease the job of public administrators by giving bureaucrats a more realistic set of goals to accomplish.

Although these suggestions have proved controversial, ${ }^{13}$ they do, I believe, respond to fundamental weaknesses in American public law. In contrast, other proposed reforms, with more salience in the current reform debate, do not. In particular, the alternatives of regulatory negotiation and restricted judicial review are inadequate if one accepts my basic commitment to both the democratic legitimacy of the administrative process and the need for an expert bureaucracy.

To evaluate the current debate over American administrative law, I contrast our system with Germany's quite different structure. I use environmental regulation as an example because achieving a balance between democratic legitimacy and technical knowledge is hardest, and most important, in areas - like environmental policy - in which expertise is essential and the interests of consumers, labor, industry, and local residents are opposed. Germany and the United States have faced remarkably similar challenges in the administration of environmental policy. Because the complex nature of environmental problems prevents legislators from resolving all issues within the text of statutes, legislatures in both countries have delegated policymaking authority to the executive.

Germany and the United States diverge sharply, however, in the external constraints they impose on high-level bureaucrats. The German public law system focuses mainly on the protection of individual rights against the state, rather than on the oversight of executive processes. No judicially enforceable statute governs ministerial policymaking processes. German administrative law thus has much in common with the proposals of two very different groups of American reformers: those who support more consensual processes and those who advocate restricted judicial review. Justice Scalia, for one, would be at home in Germany.

Germany provides a benchmark for the domestic debate because at first glance its system of administrative law and public policymaking seems an ideal response to the pathologies of the American system; many of the problems that American commentators find so vexing do not arise in Germany. I will argue, however, that adoption of the German system would be one more illustration of the dangers inherent in getting what one says one wants - recall the movie hero who

12 See Rose-Ackerman, supra note 6, at 43-79.

${ }^{13}$ See the following reviews: John J. Donohue III, Book Review, 13 J. PoL'y ANalysis \& MGMT. I92, 194-96 (1994); Daniel A. Farber, Revitalizing Regulation, 91 MrCH. L. REv. 1278, I293-96 (I993); John M. Quigley, Book Review, 3I J. ECON. Literature 200I, 2001 (I993). 
wishes for a quiet life in the country surrounded by women and wakes up to find himself transformed into a nun. ${ }^{14}$

\section{REFORM PROPOSALS}

I focus on two contrasting reform proposals for the United States, both of which can be critically examined in light of the German experience. One group of reformers deplores the adversarial quality of the administrative process and urges the adoption of consensusbuilding procedures. These critics would limit the role of the courts by reducing the incentives to appeal to them. The second group argues that judicial review of the administrative process should focus on the preservation of individual rights in the face of state power. These reformers insist that the courts should restrict their own jurisdiction.

\section{A. Consensual Processes and Environmental Protection}

Those who favor negotiated solutions recommend regulatory negotiation, business-government cooperation, and advisory committee structures. The aim is to streamline and speed up the regulatory process by fostering an atmosphere of trust and cooperation among the affected groups. Greater use of consensual processes has won support from the Administrative Conference and from a variety of reform-minded observers. ${ }^{15}$

Such reforms have recently taken statutory form in the Negotiated Rulemaking Act of I990, which encourages the use of regulatory negotiation to draft proposed rules. ${ }^{16}$ Under the Act, representatives of the affected interests meet with an agency representative and attempt to work out a compromise with the help of a "facilitator."17 The Administrative Procedure Act (APA) requires agencies to complete the informal rulemaking process, ${ }^{18}$ and still permits judicial review, but a successful negotiation should limit the range of disputes and save time. The I 990 Act is admittedly too new to be evaluated

14 The movie Bedazzled is a modern British retelling of the Faust legend. See BedazzLed (Twentieth Century Fox I968).

${ }^{15}$ See I C.F.R. $\S 305.82-4, .85-5$ (1993) (presenting the proposals of the Administrative Conference of the United States); Negotiated Rulemaking Sourcebook passim (David M. Pritzker \& Deborah S. Dalton eds., I990); Philip J. Harter, Negotiating Regulations: A Cure for Malaise, 7 I GEo. L.J. I, 28-31, 42-1 I8 (1982).

${ }^{16}$ See 5 U.S.C. $\$ \$ 561-570$ (Supp. IV 1992). The Administrative Dispute Resolution Act, $i d$. $\$ \$ 57 \mathrm{I}-583$, authorizes the use of alternative dispute resolution techniques in the implementation of statutes in particular cases.

${ }_{17} \mathrm{See} i d . \$ 566$.

${ }^{18}$ See 5 U.S.C. $\S 553$ (1988). 
confidently. Nevertheless, experience under older laws suggests that success will require careful issue selection and process design. ${ }^{19}$

Regulatory negotiation is not suitable for most environmental policy issues, in part because many environmental programs are designed to correct market failures. A scarce resource, such as air or water, is used as if it were free, causing uncompensated harm to the population. In principle, the market failure could be corrected and the gains redistributed so that everyone would be better off. The existence of net gains makes the problem appear amenable to a negotiated solution. In practice, this is seldom the case. Several fundamental problems stand in the way of negotiation, including the difficulty of finding a manageable number of truly representative participants, sharp disagreements about the distribution of gains and losses, and the need to develop a knowledge base derived from scientific principles. ${ }^{20}$ Thus, application of regulatory negotiation to market failures in the environmental field ought to be limited to cases in which these basic difficulties can be resolved.

In order to resolve these difficulties, administrative officials must be able to do three things. First, they must identify those affected by the negotiation, and ensure that all of the affected parties are represented effectively by organized groups. ${ }^{21}$ Diffuse, unorganized interests - like consumers or those who breathe the air - will be hard to represent, ${ }^{22}$ and groups that claim to speak for such individuals will have difficulty proving their claims. These problems of representation mean that negotiation is not useful for complex environmental harms that affect millions of people spread out over large geographic areas. $^{23}$ In contrast, alternative dispute resolution techniques may succeed in bringing together people affected by specific government choices that have determinate local environmental effects. ${ }^{24}$ Alternatively, a two-step process might be used: experts could come to a consensus on technical matters, and their negotiated consensus could

19 See Negotiated Rulemaking Sourcebook, supra note 15, at 327-43; Henry H. Perritt, Jr., Negotiated Rulemaking in Practice, 5 J. PoL'y ANALysis \& MGMT. 482, 484-85 (1986).

20 For example, a recent negotiation over rules for disinfectants and disinfection byproducts in drinking water was stymied by the lack of scientific data. The negotiators themselves recommended additional spending on research. See Disinfectant/Byproduct Negotiation Process Leaves Scientific Gaps, Advisory Board Says, 24 Env't Rep. (BNA) 1201, 1201 (Oct. 29, I993).

21 The groups must not be deeply divided within themselves, and they must all be represented by competent and well-informed people. See 5 U.S.C. $\$ 56_{3}$; Perritt, supra note I9, at $484-85$.

22 See Perritt, supra note 19 , at 485.

${ }^{23}$ See Rudolf Steinberg, Kritik von Verhandlungslösungen, insbesondere von mittlerunterstïtzten Entscheidungen, in I KONFLIKTBEWÄLTIGUNG DURCH VERHANDLUNGEN 295, 304-05 (Wolfgang Hoffmann-Riem \& Eberhard Schmidt-Aßmann eds., I99o) (arguing that negotiated solutions are not suitable for rulings that affect large numbers of people).

24 See 5 U.S.C. $\$ \S 571-583$. 
then serve as a starting point for ordinary notice-and-comment rulemaking. ${ }^{25}$

Second, even if the representation problem can be solved, the authorities must clarify exactly which decisions the negotiation group is to make and which decisions will be left to the bureaucracy. They must also provide the basic framework of scientific and technical knowledge. The public officials must explain how they will reach a decision if the negotiation fails. This is a key strategic step that affects both the probability of a successful result and the acceptability of the outcome. If the decision is to be made by consensus, the different groups will only agree if all of them are better off under that choice than under the fallback position. ${ }^{26}$

Third, the authorities must determine the ground rules. Regulatory negotiation is predicated on reaching a consensus. But consensus can be sought by many methods. Considerable controversy has centered around the form of the negotiation. Should government officials participate?27 Should meetings be open or private? ${ }^{28}$ Should a mediator or moderator guide the process? ${ }^{29}$ Should the authorities supply experts to evaluate the technical aspects of the problem?30 If the system of representation is satisfactory, government officials need not attend, and meetings can be private. If it is not, the addition of bureaucrats and the creation of a more open process are unlikely to compensate satisfactorily for this failure. In such cases, the state should either follow normal APA requirements or submit the issue to the legislature for resolution by majoritarian processes.

In short, regulatory negotiation should have only limited applicability to the environmental field. It is only appropriate for a certain narrow class of issues, and even for those issues the process must be carefully designed if democratic legitimacy is to be preserved and an

25 The problem with such a process is that important options might be eliminated by technocrats and public officials at the first stage, before citizens are given a right to participate in a public hearing. In the German context, see Bernd Holznagel, Mittlerunterstiitzte Aushandlungsprozesse aus Anlaß abfallrechtlicher Planfeststellungsverfahren, in WANDEL DER HANDLUNGSFORMEN IM OFFENTLICHEN RECHT 99, I06-13 (Kathrin Becker-Schwarze, Wolfgang Köck, Thomas Kupka \& Matthias von Schwanenflügel eds., 199r); and Steinberg, cited above in note 23 , at $3 \mathrm{II}$.

${ }^{26}$ See Perritt, supra note 19 , at 484 .

27 See, e.g., 5 U.S.C. $\$ \S 565(\mathrm{~b}), 566$ (b) (requiring the participation of agency representatives); Perritt, supra note 19 , at 490 (recommending the participation of government officials).

${ }^{28}$ See, e.g., Perritt, supra note 19 , at 486-87 (recommending private meetings).

${ }^{29} \mathrm{See}, e . g ., 5$ U.S.C. $\$ \S 563(\mathrm{~b}), 566(\mathrm{c}), 568,569$ (providing for both a convener and a facilitator).

${ }^{30}$ See, e.g., Wolfgang Hoffmann-Riem, Verhandlungslösungen und Mittlereinsalz im Bereich der Verwaltung: Eine vergleichende Einführung, in I KONFLIKTBEWäLTIGUNG DURCH VERHANDLUNGEN, supra note 23 , at $\mathrm{I} 3,2 \mathrm{I}-23$ (discussing the use of technical experts in regulatory negotiation in the German legal context). 
acceptable outcome reached. As we shall see when we examine the German system, consensual processes are not necessarily desirable.

\section{B. Restrictions on Judicial Review}

Justice Antonin Scalia is the chief American judicial advocate of sharp restrictions on judicial review. According to Justice Scalia, the courts should avoid the political issues that arise in the oversight of the rulemaking process. He argues that reviewing courts should give only those who have suffered individual injuries standing to raise issues related to violations of their rights. Agencies, freed from intrusive court review, would then be able to revamp the administrative process for greater efficiency. Statutory deadlines could be met more frequently, and less agency time would be taken up with defending against court challenges. To clarify Justice Scalia's position, consider two recent Supreme Court opinions that denied standing to organized wildlife groups that sought to challenge government actions.

In Lujan v. National Wildlife Federation, ${ }^{31}$ a wildlife group challenged the Federal Bureau of Land Management's land classification policy, which had opened up certain lands to mining. In a five-tofour decision, the Court denied the group standing. ${ }^{32}$ In dicta, ${ }^{33}$ Justice Scalia went on to discuss preenforcement review of regulations, ${ }^{34}$ which he argued should be a narrow exception to the general rule that:

a regulation is not ordinarily considered . . . "ripe" for judicial review under the APA until the scope of the controversy has been reduced to more manageable proportions, and its factual components fleshed out, by some concrete action applying the regulation to the claimant's situation in a fashion that harms or threatens to harm him. ${ }^{35}$

Justice Scalia thus took the opportunity to criticize attempts to influence agency policymaking through the courts. General acceptance of Justice Scalia's position would make review of high-level policymaking more difficult. It would make challenges mounted by environmental groups especially problematic because regulations are seldom directed at them.

Justice Scalia seems to have gone even further in the second case, although the actual breadth of the Court's holding is in some doubt. Lujan v. Defenders of Wildlife ${ }^{36}$ concerned a wildlife group's challenge

${ }^{31} 497$ U.S. 87 I (1990).

32 See id. at 885-89.

${ }^{33}$ See id. at $91_{3}$ (Blackmun, J., dissenting) (arguing that Justice Scalia's discussion of preenforcement review of regulations is dictum).

34 The seminal case in this area is Abbott Laboratories v. Gardner, 387 U.S. 136 (1967).

${ }^{35}$ National Wildlife Fed'n, 497 U.S. at 89 r.

36 II2 S. Ct. 2 I30 (I992). 
to a rule that limits the scope of the Endangered Species Act of 1973 to actions within the United States and on the high seas. Two members of the group had traveled to Egypt and Sri Lanka and stated that they intended to return. Writing for the Court, Justice Scalia denied standing. 37

Not content to rest there, Justice Scalia proceeded to deal with the issue of "procedural injury." The court of appeals had held that the citizen-suit provisions of the Endangered Species Act gave the wildlife group standing to seek court review of executive branch consultation procedures. Justice Scalia rejected this reasoning:

This is not a case where plaintiffs are seeking to enforce a procedural requirement the disregard of which could impair a separate concrete interest of theirs . . . . Rather, the court held that the injury-in-fact requirement had been satisfied by congressional conferral upon all persons of an abstract, self-contained, non-instrumental "right" to have the Executive observe the procedures required by law. We reject this view. ${ }^{38}$

Justice Scalia recognized that procedural rights have a special status when concrete interests are at stake. ${ }^{39}$ But his opinion rejected in strong terms the notion that courts may vindicate the public interest ${ }^{40}$ - this is the function of Congress and the president. Justice Scalia thus denies that it is legitimate for Congress to use the courts to monitor the executive.

Most environmental statutes include provisions for citizen suits, ${ }^{41}$ and recognize public interest groups as "citizens." In the course of criticizing Justice Scalia's opinion in Defenders of Wildlife, Cass Sunstein argues that the decision held all such citizen suits unconstitutional, because the statutory provisions seldom require the impairment of a "separate concrete interest" of the plaintiff. ${ }^{42}$ Professor Sunstein goes too far when he elevates Justice Scalia's strong language to the status of constitutional law, but he has raised the possibility that

${ }^{37}$ See id. at $2137-40$.

38 Id. at $2142-43$.

${ }^{39}$ In such cases, requirements of redressability and immediacy can be waived. See id. at $2 \mathrm{I}_{42}$ n.7.

$40 \mathrm{See}$ id. at $2 \mathrm{I} 45$.

41 See Federal Water Pollution Control Act $\S 505,33$ U.S.C. \& 1365 (1988); Oil Pollution Act $\S$ Ior 7, 33 U.S.C. $\$ 2717$ (Supp. II I990); Resource Conservation and Recovery Act $\S 7002$, 42 U.S.C. § 6972 (rg88); Clean Air Act § 707, 42 U.S.C. § 7604 (1988 \& Supp. II 1990); Comprehensive Environmental Response, Compensation, and Liability Act $\S$ II3, 42 U.S.C. $\S 9659$ (1988). The one exception is the Federal Insecticide, Fungicide, and Rodenticide Act, 7 U.S.C. $\$ \S \mathrm{r} 36-\mathrm{r} 36 \mathrm{y}$ (r988).

${ }^{42}$ See Cass R. Sunstein, What's Standing After Lujan? Of Citizen Suits, "Injtries," and Article III, 9I MrCH. L. REv. 163, 200-02 (1992). 
Justice Scalia's musings could gain constitutional status in some future case. 43

Justice Scalia's position ignores the value of the basic principles of informal rulemaking and judicial review under the APA. He seeks to rule out just the sort of judicial review that the courts are best able to perform without taking on a policymaking role. ${ }^{44}$ Under the APA the ultimate policymaking decision is in the hands of the bureaucracy, but administrative discretion is constrained by the need for public notice, a hearing, and a statement of reasons. 45 Thus, the process is open to opinions and information from outside groups, but it is not under the control of these groups. Such bureaucrat-led processes are generally appropriate in the environmental area, because of the problems of representation. Bureaucratic discretion is subject to judicial review both of procedure and of substance under an "arbitrary and capricious" standard. ${ }^{46}$ Although statutory and judicial overlays may have unduly elaborated the APA provisions, the basic structure should not be abandoned. To follow Justice Scalia's line would be to overlook the important role courts have to play in ensuring the democratic legitimacy of bureaucratic procedures under the American separationof-powers doctrine.

\section{The German Disadvantage in Administrative PROCEDURE ${ }^{47}$}

So far I have argued that neither advocates of regulatory negotiation nor supporters of reduced judicial oversight have offered acceptable solutions to the problems of the American regulatory state. A study of the German system confirms the inadequacy of these

${ }^{43}$ Contrary to Sunstein's view, Justice Scalia's opinion did not clearly delineate the limits of congressional authority to include citizen suit provisions in legislation. Commenting on this issue, Justice Kennedy, joined by Justice Souter, stated that "Congress has the power to define injuries and articulate chains of causation that will give rise to a case or controversy where none existed before, and I do not read the Court's opinion to suggest a contrary view." Defenders of Wildlife, II2 S. Ct. at 2146-47 (Kennedy, J., concurring in part and concurring in the judgment). Presumably, if Justices Kennedy and Souter had read Justice Scalia's language to express this "contrary view," they would not have concurred in his opinion. Furthermore, Justice Stevens, who concurred only in the judgment, took a broad view of citizen and group standing. See id. at $2 \mathrm{I}_{47}$ (Stevens, J., concurring in the judgment). If these three Justices are combined with the two dissenters, Justices Blackmun and O'Connor, it appears that five members of the Court take a permissive view of Congress's ability to define the injuries that can create standing.

44 See id. at 2158 (Blackmun, J., dissenting) (criticizing the opinion's "anachronistically formal view of the separation of powers").

45 See 5 U.S.C. $\$ 553$.

${ }^{46}$ See id. $\$ 706$.

47 With apologies to John H. Langbein. See John H. Langbein, The German Advantage in Civil Procedure, 52 U. CHI. L. REv. 823 (I985). 
proposed reforms. Germany's environmental policymaking processes and its restricted system of judicial review fail to provide democratic legitimacy - at least as that phrase is understood in American democratic theory.

\section{A. Legislative and Constitutional Structure}

The centrality of party politics in the German political system has profound implications for the process of environmental policymaking. Although Germany's system of proportional representation facilitated the creation of a Green party, ${ }^{48}$ it may also have discouraged other, extra-parliamentary forms of policy activism. According to German views of democracy, individuals who oppose the policies of the governing coalition should focus on changing the government through electoral, party politics, rather than by influencing day-to-day policymaking. ${ }^{49}$ In addition, because the same party coalition controls both the legislative and executive branches, formal legal constraints on bureaucratic policymaking should be unnecessary.

The German reality - at least in the area of environmental policy - is not nearly so well ordered as the theory suggests. German statutes are not precise statements of policy, but are full of vague and undefined terms that require further interpretation before the acts can be implemented. Because of the complex technical nature of environmental issues and because of the difficult tradeoffs faced by those seeking to control pollution, the Bundestag has been no more successful at giving clear direction to the executive than the United States Congress has been.

The German approach differs from the American, however, because Germany's constitution, the Grundgesetz, 50 explicitly limits the regulatory activity of the executive. Before a regulation can be issued, the Grundgesetz requires the Bundestag to delegate regulatory authority by specifying the "content, purpose, and scope" of the authorization in the statutory language. ${ }^{51}$ In addition, the substantive, judge-made principle of "proportionality" constrains both legislative and executive

48 The Green Party has been in the Bundestag since 1983 and is part of the coalition government in several Länder. See Edda Müller, Sozial-liberale Umweltpolitik: Von der Karriere eines neuen Politikbereichs, Das Parlament (Supp., Aus Politik und Zeitgeschichte), Nov, I7, I 989 , at 3 , II.

49 See Peter J. Katzenstein, Policy and Politics in West Germany 44 (1987) (arguing that German political parties are "an essential institutional node linking state and society").

50 The foundational document promulgated in 1949 was called a Basic Law (Grundgesetz) rather than a constitution to emphasize the provisional character of the divided German state. In this Article, however, I will use the terms "Grundgesetz" and "constitution" interchangeably.

51 See Grundgesetz [GG] art. 80(I); see also Theodor Maunz, GUNTER DURIG, Roman Herzog, Rupert Scholz, Hans-Júrgen Papier, Albrecht Randelzhofer \& Eberhard SCHMIDT-AssmanN, 3 GRUNDGESETZ: KoMmentar, art. 80, at 5 (1993) (explaining the constitutional mandate of delegation of regulatory authority). 
policymaking. This principle has four parts: ${ }^{52}$ first, the aim of the law must be legitimate; second, the means must be in proportion to the ends; third, the means must be an effective way of reaching the ends; and fourth, the means must intrude as little as possible upon individual rights. Both the delegation doctrine and the proportionality principle could, in theory, impose strong checks on legislative draftsmen and executive-branch policymaking, but in practice they impose only modest constraints. ${ }^{53}$

Another important constraint on federal regulatory activity in Germany is the constitutional requirement that the upper house of the legislature, the Bundesrat, approve all regulations and guidelines that the states will administer. ${ }^{54}$ Because Germany's federal system delegates most implementation to the states, ${ }^{55}$ the Bundesrat enjoys veto power over a wide range of executive branch activity, including all major environmental initiatives. As state government officials, Bundesrat members are, however, generally more concerned with the ease of implementation than with the merit of the substantive policies. ${ }^{56}$

\section{B. The Administrative Process}

German law places few limitations on governmental rulemaking procedures. Constitutional doctrines do not regulate high-level administrative processes. Once the Constitutional Court accepts the constitutionality of a substantive government action, it inquires no further into the procedural details. Statutory law has not filled this gap. The German Administrative Procedure Act governs the behavior of public agencies only when they implement general policies in particular cases. ${ }^{57}$ It does not apply to the formulation of legal regulations and administrative guidelines.

Unlike the American rulemaking process, German law imposes few procedural constraints on the activities of the Environmental Ministry. Officials are free to assign aspects of their tasks to outside

52 The principle is said by the courts and commentators to derive from the fundamental rights protected by the Grundgesetz. See THEODOR MAUNz \& REINHOLd Zippelius,

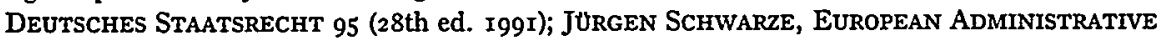
LAW 688 (1992).

53 See Susan Rose-Ackerman, Controlling Environmental Policy: The Limits of Public Law in Germany and the United States ch. 6 (forthcoming I994) (arguing that, in practice, German courts do not strictly apply the proportionality principle in complex technical matters).

54 See GG arts. 80(2), 84(2), 85(2). The Bundesrat is composed of members of state governments, with votes apportioned roughly by population. See GG arts. 50-53.

55 See GG arts. 83-85; KATZENSTEIN, supra note 49 , at 20.

56 See ROSE-ACKeRmaN, supra note 53 , ch. 5 .

57 See Verwaltungsverfahrensgesetz [VwVfG] § 35, 5976 Bundesgesetzblatt [BGBl.] I I253, 1263. 
groups, state-federal working groups, or advisory bodies. Typically, the ministry seeks advice from such groups before instituting more formal procedures. The process lacks adequate procedural safeguards, and in a few cases even the usual formalities can be avoided. ${ }^{58}$

I. Consensual Processes. - In practice, the German government delegates certain technical decisions to private groups and routinely consults with federal advisory committees of experts and interest group representatives in the course of setting environmental standards. These consensual practices, derived from labor-management relations and industrial self-regulation, ${ }^{59}$ are often poorly adapted to environmental issues ${ }^{60}$ and demonstrate the risks of an uncritical endorsement of regulation through negotiation.

(a) Private Norm-setting Organizations. - Private norm-setting organizations have long played a key role in the self-regulation of economic activity outside the environmental arena. ${ }^{61}$ Their original role as standard-setters for industry now extends into the environmental field. ${ }^{62}$ The most important norm-setting organizations are the German Institute for Norms (Deutsches Institut für Normung, DIN) ${ }^{63}$

58 See infra p. 1300.

${ }^{59}$ See Katzenstein, supra note 49 , at 58-64; see also THE Regulation Game: How British and West German Companies Bargain With Government 152-54 (Alan Peacock ed., I984) (demonstrating that the German administrative system encourages negotiation between firms and regulators).

60 See ROSE-ACKERMAN, supra note 53, ch. 8 (discussing the difficulties that arose when Germany experimented with regulatory negotiation in environmental cases). For general works on the role of negotiation in German environmental law, see I KoNFLiKTBEWÄLTIGUNG DURCH VERHANDLUNGEN, cited above in note 23 , at 217-335; and BERND HolzNAGEL, KONFLikTLOSUNG DURCH VERHANDLUNGEN 177-302 (1990).

61 There are 170 such bodies in Germany. See Klaus Grefen, Harmonization of Technical Rules for Clean Air in View of the European Internal Market 3 (Nov. 1991) (unpublished manuscript, on file with the Harvard Law School Library). The legal status of the norms that these groups set is a controversial issue in German law. See Gert Brüggemeier \& Josef Falke, Product Safety Policy in the Federal Republic of Germany, in European Product SaFeTy, INTERnal Market Policy and the NeW Approach to TechniCal HaRMonisation and Standards I, 8-12 (Christian Joerges ed., r991); Peter Marburger, Die gleilende Verweisung aus der Sicht der Wissenschaft, in VerweISUNG aUF TECHNISCHE NORMEN IN RECHTSVORSCHRIFTEN: SYMPOSIUM 27, 39 (Deutsches Institut für Normung ed., 1982).

62 See Erhard Denninger, Verfassungsrechtliche ANForderungen an die NormSETZUNG IM UMWELT- UND TECHNIKRECHT I3 (1990) (describing the principle of "cooperation" between governmental organs and non-governmental organizations in the area of environmental protection); Martin Führ, Technische Normen in demokratischer Gesellschaft, 4 ZEITSCHRIFT FUR UMWELTRECHT 99, 99 (1993); Irene Lamb, Die Bedeutung technischer Normen im Umweltrecht, 4 ZEITSCHRIFT FUR UMWELTRECHT 97, 99 (1993); Gertrude Lübbe-Wolff, Verfassungsrechtliche Fragen der Normsetzung und Normkonkretisienung im Umweltrecht, 6 ZEITSCHRIFT FUR GESETZGEBUNG 2I9, 22 I (I99I).

63 See Brüggemeier \& Falke, supra note 61, at 50-74; Führ, supra note 62, at 101-02; Lamb, supra note 62, at 97. As of I990, the DIN had 20,988 standards on its books. Almost 4000 working groups of the DIN exist to set standards in a variety of fields. See Grefen, supra note $6 \mathrm{I}$, at 15 , tbl. 3. The DIN contract with the federal government, which dates from 1975 , 
and the Association of German Engineers (Verein Deutscher Ingenieure, VDI). ${ }^{64}$ The DIN has a committee for nuclear engineering, and in I990 the DIN and the VDI established a Commission on Air Pollution Prevention with financial support from the federal government. ${ }^{65}$ In addition to the self-regulation these organizations support, the Environmental Ministry has sometimes used their standards as guides to the implementation of statutes in the environmental area.

The use of norms generated by private technical groups can introduce systematic bias into the policymaking process. Consider the VDI-DIN Commission on Air Pollution Prevention. Although there are some representatives of government on the Commission, membership is heavily weighted toward experts employed by industry, and environmental groups are not represented at all. ${ }^{66}$ In addition, although committee members are "volunteers," the members' employers, rather than the individuals themselves, bear the cost of participation. As a consequence, many critics have charged that industrial interests are overrepresented. ${ }^{67}$

After preliminary proposals have been formulated in private committee meetings, they are made available to the public, including environmental groups, for comment. The committee formulates a final recommendation, which may incorporate these comments. ${ }^{68}$ Environmental groups, however, often lack the necessary financial and technical resources to provide effective review within the time constraints of the public comment process. ${ }^{69}$

Because the committees do not have the relevant expertise and do not adequately represent all the affected interests, and because the excluded interests cannot provide effective review, the influence of private norm-setting organizations is troubling. ${ }^{70}$ The problem is

requires the DIN to take the public interest into account when setting standards. See Christoph Gusy, Wertungen und Interessen in der technischen Normung, 6 UMWELT- UND PLANUNGSRECHT 24I, 245 (Ig86).

64 The VDI, founded in 1856 , has 110,000 individual members. See Grefen, supra note 6I, at 2. Also important are the Verband Deutscher Elektrotechniker (VDE) and the Deutscher Verein des Gas- und Wasserfaches (DVGW). See DeNNINGER, supra note 62, at 78 .

65 See Kommission Reinhaltung DER LUFT IM VDI UND DIN, AUfBaU, Aufgaben, ERGEBNISSE I-7 (I99I); Grefen, supra note 6r, at 3.

66 In contrast, DIN consumer product standard committees have included representatives of consumer groups since I974. See Brüggemeier \& Falke, supra note 6I, at 68-72.

${ }^{67}$ See Heiko Wagener, Der Anspruch auf Immissionsschutz: Plädoyer für ein einklagbares Recht, 2 NATUR UND Recht 7r, 74 (1988) (noting that the VDI-DIN Commission on Air Pollution Prevention is biased in favor of industry).

${ }^{68}$ See Führ, supra note 62, at IoI; Gusy, supra note 63, at 246; Lübbe-Wolff, supra note 62 , at 229.

${ }^{69}$ See Führ, supra note 62 , at ror.

${ }^{70}$ Several German administrative law scholars have urged both reduced reliance on the recommendations of private groups and increased transparency in the standard-setting processes used by these groups. See Fritz Ossenbühl, Informelles Hoheitshandeln im Gesundheits- und 
broader than the possible biases introduced by the members' institutional affiliations. The VDI-DIN Commission's members are primarily engineers and natural scientists, with only a smattering of social scientists. Indeed, economists are in a residual, five-percent category along with "lawyers, ... art historians, and other disciplines."71 Even highly competent scientists and engineers are unlikely to be sensitive to the broader social implications of their recommendations. Because environmental problems cannot be neatly divided into technical and political segments, judgments will necessarily involve a balancing of costs and benefits. ${ }^{72}$ Engineers do not necessarily make good policy analysts. Engineers' resolutions of mixed issues of technology and policy tend toward "standard-setting" rather than toward a more nuanced view of the link between means and ends.

This is not to say, of course, that the United States has found just the right mixture of engineering and social science. It has not. American policy is frequently criticized for favoring technical fixes over performance standards or tradable rights. The United States and Germany face similar substantive failures of policy. ${ }^{73}$ However, the fact that engineering and technical groups play a smaller role in the American administrative process suggests that new policy-oriented ideas from the social sciences may gain acceptance more easily in the United States. The German model of consensual development of technical standards, by contrast, overemphasizes engineering solutions and limits public access to the process. ${ }^{74}$ Even if the private normsetting groups included a broader range of experts, they would still face the limitations of any technical body called upon to make policy judgments.

(b) Advisory Committees. - Although German private standardsetting organizations frequently recommend technical standards, these groups have no formal decisionmaking authority. The ministry or the cabinet holds ultimate responsibility for legal regulations and guidelines, subject to Bundesrat approval. To provide further outside as-

Umweltschutz, 3 JAHRBUCH DES UMWELT- UND TECHNIKRECHTS 27, 47 (1987); see also DENNINGER, supra note 62, at 195 (arguing that the constitutional "Democracy Principle" forbids too much delegation of standard-setting power to non-governmental organizations); Lübbe-Wolff, supra note 62 , at 248 (advocating greater openness and transparency in environmental normsetting).

71 KoMmission REINHALTUNG DER LUFT IM VDI UND DIN, supra note 65 , at 2, tbl. 1 .

72 Policy analysis is not a well-developed field in Germany. For instance, the Umwellbundesamt, the technical advisory body to the Environmental Ministry, consists largely of scientists and engineers. Of the 417 professionals employed by the Umweltbundesamt in 1991, only 15 had a degree in economics, and 18 in political science or psychology. See Umweltbundesamt, ANNUAL REPorT rg91: ENGLISH SUMMARY 6 (1992).

${ }^{73}$ For an overview of the weaknesses in the German and American systems, see RoSEACKERMAN, cited above in note 53 , ch. 3 .

74 For an effort by the Administrative Conference of the United States to grapple with these issues, see I C.F.R. § 305.78-4 (I993). 
sistance - political as well as technical - several statutes require that the ministry seek advice from advisory committees that include representatives of industry, labor, science and, occasionally, environmental or consumer groups. The composition of the committee may be specified by law, but the ministry selects the individual members.

Consider, for example, the regulation of nuclear power in Germany. There are three main governmental advisory committees, all of which are dominated by the power industry or by scientists with a commitment to nuclear power. ${ }^{75}$ The Nuclear Technology Committee (Kerntechnischer Ausschuß), for example, fails to ensure broad representation of interests. ${ }^{76}$ Of the Committee's fifty members, ten represent producers and builders of nuclear equipment and plants, ten represent power companies, ten represent state and federal regulatory agencies, ten represent expert bodies, and the remaining ten represent a diverse collection of groups. The committee votes using a five-sixths rule, so that any of the five groups can block any action.

All of the advisory committees are subject to the same criticisms as the DIN and the VDI. The committees seem to be too much under the sway of the regulated industry and of the scientists whose livelihood depends on the industry's continued viability. ${ }^{77}$ American observers who praise the cooperative regulatory environment in Germany ${ }^{78}$ need to acknowledge that such advisory bodies frequently have an unrepresentative character.

Defenders of the German system take a broader view of the political landscape. Ronald Czada, a student of German nuclear-power regulation, argues, for instance, that the system maintains a reasonable balance between industry and the public interest. ${ }^{79}$ Although the advisory committees are dominated by industry, and day-to-day implementation is carried out by self-regulatory bodies, he argues that the industry as a whole is concerned with safety because it fears antinuclear political action. He claims that German producers of nuclear power will try to avoid a major accident because of the severe political repercussions that would follow.

75 See Roland Czada, Konfliktbewältigung und politische Reform in vernetzten Entscheidungsstrukturen: Das Beispiel der kerntechnischen Sicherheitsregulierung, in VERHANDLUNGSDEMOKRatie, InteressenvermittuUng, Regierbarkeit 73, 78-79 (Roland Czada \& Manfred G. Schmidt eds., 1993); Rudolf Steinberg, Untergesetzliche Regelwerke und Gremien, in REFORM DES ATOMRECHTS (Rudolf Steinberg ed., forthcoming r994) (manuscript at I7, on file with the Harvard Law School Library).

76 See Ossenbühl, supra note 70, at 4I-42; Steinberg, supra note 75, at I2 \& n.43.

77 See Führ, supra note 62, at Ior; see also Steinberg, supra note 75, at I7 (arguing that the technical standards set by advisory committees essentially determine the content of laws and regulations).

78 See, e.g., Richard B. Stewart, Environmental Regulation and International Competitiveness, I02 YALE L.J. 2039, 2083 (1993) (arguing that other developed countries, including Germany, have more flexible and cooperative systems of environmental regulation).

${ }^{79}$ See Czada, supra note 75, at 79-8I. 
This sanguine view of the current situation raises an important question: are the concerns of environmentalists best incorporated into the regulatory process by giving such groups direct access to decision-making institutions or by letting their political protests act as a background constraint? The German public law tradition takes the view that outside protest, rather than inside participation, is the better course. I claim that direct access - more typical of the American policymaking process - is ultimately more conducive to good policy and is more democratically legitimate. American environmentalists cannot content themselves with being gadflies, but need to become well-informed, technically sophisticated participants in the environmental policymaking process. Mobilization is not sufficient. Influence comes primarily, not from being a nuisance, but from rational argumentation and from having an informed constituency.

2. Public Participation and Information. - Using the output of the private norm-setting groups, advisory committees, and state-federal working groups, the German Environmental Ministry proposes draft regulations and guidelines to the cabinet. This process is informal, private, consensual, and unreviewable. Ministry proceedings need not be accompanied by public notice, public hearings, or a statement of reasons. There is no judicial review of the adequacy of representation, and the public has no general right of access either to executive branch officials or to the information that they possess. ${ }^{80}$

Members of the public have a legal right to obtain information held by the government only if they can demonstrate a suspected violation of their individual rights in the context of an administrative proceeding. ${ }^{81}$ A European Community directive, however, requires member states to pass laws that permit access to environmental information without a demonstration that anyone's rights have been violated. ${ }^{82}$ Although draft laws under this directive have been proposed in Germany, controversy over the breadth of the term "environmental information" has meant that no statute has yet passed. ${ }^{83}$

Moreover, although environmental groups do participate in certain lower-level planning and licensing processes, the government is under no legal obligation to consult with them. ${ }^{84}$ An internal government

80 See Rose-ACKeRMaN, supra note 53 , ch. 5 .

81 The statute guarantees access, first, only to files that are defined as part of an "administrative process," see VwVfG § 9, $1976 \mathrm{BGBl}$. I 1253, 1257, and second, only to those who have a personal legal interest in obtaining access to the files, see VwVfG § 29, 1976 BGBl. I 1253, I26I.

82 See Council Directive $90 / 3 \mathrm{I} 3$ of 7 June 1990 on the Freedom of Access to Information on the Environment, art. 3, I990 O.J. (L I58) 56, 57.

83 See ROSE-ACKERMAN, supra note 53, ch. 9.

${ }^{84}$ See Ulrich Linse, Dieter Rucht, Winfried Kretschmer \& Reinhard Falter, Von der Bittschrift zur Platzbesetzung: Ein Vergleich, in VoN DER BITTSCHRIFT zUR PI.ATZBESETzUNG: KONFLikTE UM TECHNISCHE GRosSPROJEKTE 231-43 (Ulrich Linse, Reinhard Falter, Dieter 
ordinance states that ministries should consult with interested groups, but provides no enforcement mechanism. ${ }^{85}$ Some statutes specify the interests that should be consulted when rules and guidelines are promulgated, but environmental organizations and public interest groups are seldom included in these lists. ${ }^{86}$ Because compliance with these provisions is not subject to judicial review, the statutory language is, in any event, little more than a recommendation. ${ }^{87}$

Of course, political imperatives will frequently make broad-based consultation expedient, and environmental groups are often asked to present their views. Even under reformed procedures, however, the influence of environmental interests in Germany would be more limited than it is in the United States. Private environmental groups are numerous, but few have the technical capacity to mount a serious challenge to the conventional policymaking and standard-setting process. ${ }^{88}$ Strong private groups would be unnecessary if political parties such as the Greens could provide a viable substitute; but under mod-

Rucht \& Winfried Kretschmer eds., I988); Rose-AckeRMaN, supra note 53, ch. 7. The only explicit provision for participation of organized groups is in the Nature Protection Law, which permits a limited number of state-designated groups to participate in some state and local planning processes. See Naturschutzgesetz [NatSchG] § 29, x987 BGBl. I 889, 902-03.

85 The ordinances that govern the federal ministries require that they inform national organizations representing concerned interests and consult with them before a rule or guideline is issued. The plans of ministries need not be public documents, and persons consulted can be required to keep them confidential. See Gemeinsame Geschäftsordnung der Bundesministerien [GGO] II $\S \S 24,67,78$. If independent experts testify, the Ministry selects them, and their testimony is not generally made public. See GGO I $\$ 6 \mathrm{I}(3)$. These ordinances are only internal administrative rules and have no legal force. See Maunz, DUrig, Herzog, Scholz, Papier, RANDELZHOFER \& SCHMIDT-ASSMANN, supra note 5I, art. 80, at 22; Fritz Ossenbühl, Rechtsverordnung, in 3 HANDBUCH DES STAATSRECHTS DER BUNDESREPUBLIK DEUTSCHLAND 387 , 389, 4I6-I7 (Josef Isenee \& Paul Kirchhof eds., I988); see also id. at 4 I 4 (providing examples of statutes that require the participation of incorporated groups, organizations, or individual experts).

${ }^{86}$ Some statutes, such as the Federal Water Act, impose no constraints. See Wasserhaushaltsgesetz [WHG] $\$ 7$ a, I986 BGBl. I 1529, 1531; Lübbe-Wolff, supra note 62, at 228. The Air and Noise Pollution Act states that the ministry "shall hear" representatives of those directly affected as well as representatives of the scientific community, the trade, industry and traffic sectors, and the responsible Land authorities. Environmental organizations are not included in the list of "parties concerned." See Bundesimmissionsschutzgesetz [BImSchG] \& 51, I974 BGBl. I 721, 733. Compare Abfallgesetz [AbfG] \$ I6, I986 BGBl. I I4IO, I4I8 (requiring, like the Air and Noise Pollution Act, that the ministry consult with affected parties before issuing regulations) with Chemikaliengesetz [ChemG] I7 $_{1}(\mathrm{I}),(7), 1980 \mathrm{BGBl}$. I ${ }_{7718}$, I724, amended by $1990 \mathrm{BGBI}$. I 52I, 530 (including several types of public interest groups in the list of parties with whom the ministry must consult).

87 See Maunz, Durig, Herzog, Scholz, Papier, Randelzhofer \& Schmidt-Assmann, supra note 5I, art. 80, at 22; Ossenbühl, supra note 85 , at 416-I7.

88 Most environmental groups are poorly staffed and funded. See Dieter Rucht, Von der Bewegung zur Institution? Organisationsstrukturen der Ökologiebewegung, in NeUE SOZIALE BEWEgungen IN DER BundesRepublik Deutschland 334, 354-56 (Roland Roth \& Dieter Rucht eds., 2d ed. I9gI). 
ern conditions, in which much policy is made in administrative proceedings, rather than in the legislature, partisan political activity provides an insufficient review of policymaking. 89

3. Lessons for America. - The German experience with consensual procedures counsels caution. Advisory committees, federal-state working groups, and quasi-private committees of technical experts all influence German technical standards and public policies. The system is thus accountable to the scientific community, to business, and to lower-level governments. It is only indirectly accountable to the public and to the environmental community, through the cabinet's responsibility to the parliament and through the voluntary efforts of the ministry and its advisers. Although some American critics might find the resulting process close to ideal, it is ill-suited to the nature of many of the problems facing the administrative state.

German consensual processes fail to measure up to American notions of political accountability and thus are not a legitimate policy choice for the United States. Even the admission of environmental groups or citizens' organizations in an attempt to make the negotiating bodies more representative would not solve the problem. Although private groups can be an important source of information about both technical and political matters, they cannot make strong claims to represent the general public in regulatory negotiations. Environmental organizations should, of course, be heard by the bureaucracy in conventional rulemaking procedures. In the United States such groups also have the expertise and organizational capacity to challenge faulty rulemaking procedures in court. These legitimate and important roles do not, however, imply that these groups can speak for the public in regulatory negotiations. Once one admits this shortcoming, it becomes clear that even consensual decisions that involve these groups lack legitimacy. No amount of tinkering with the proceedings will overcome the fundamental mismatch between the consensual approach and the policy problem. Regulatory negotiation is not a good way to ensure the accountability of those making far-ranging environmental policy choices. The German experience supports my conclusion that consensual decisionmaking can produce legitimate decisions only in a narrow range of environmental issues.

\section{Judicial Review}

According to German democratic theory, political actors do an adequate job of monitoring bureaucratic policymaking activities.

${ }^{89} \mathrm{Green}$ activists can, however, point to their role in helping to generate popular support for a tough 1983 regulation that has reduced sulphur dioxide emissions. See Verordnung über Großfeuerungsanlagen, Bundesimmissionsschutzverordnung [BImSchV] No. 13, 1983 BGBl. I 719. But see Sonja Boehmer-Christiansen, Anglo-German Contrasts in Environmental PolicyMaking and Their Impacts in the Case of Acid Rain Abatement, 4 INT'L ENVTL. AFF. 295, 304 (I992) (calling the Greens' "success" into question). 
Thus, preenforcement review of federal administrative rules or guidelines is not available. ${ }^{90}$ The judiciary's task is, instead, to prevent the state from riding roughshod over individuals as the state pursues broad public goals. ${ }^{91}$ The German administrative courts devote most of their time to protecting individual rights, rather than to monitoring the political and policymaking activities of government. ${ }^{92}$

Rules of standing and private rights of action exemplify the German understanding of democracy. Conventional public law does not permit outsiders to challenge executive branch policies in the administrative courts unless an individual's "subjective rights" have been violated. ${ }^{93}$ The same reasoning that justifies denying individuals and groups the right to participate in the formulation of general regulations and legal guidelines ${ }^{94}$ also justifies excluding them from making direct legal challenges to these instruments in court. 95 Germany also lacks the range of private rights of action found in American law. German citizens can defend their individual rights but cannot act as private attorneys general to help enforce the law.

I. Review of Environmental Issues. - Despite the restrictions on standing and the narrow range of issues subject to judicial review, environmental organizations and individual citizens have used the German courts to raise important issues of public policy, particularly in the nuclear power area. After mounting several mass protests to

90 See Eckard Rehbinder, Controlling the Environmental Enforcement Deficit: West Germany, 24 AM. J. CoMp. L. 373, 376-77 (1976).

91 See GG art. I9(4).

92 See Carl Böhret, Public Administration in a Democracy, in Public Administration in THE FEDERAL Republic OF Germany 33,42 (Klaus König, Hans Joachim von Örtzen \& Frido Wagener eds., I983); Michael S. Greve, The Non-Reformation of Administrative Law: Standing to Sue and Public Interest Litigation in West-German Environmental Law, 22 CORNELL INT'L L.J. I97, 201-02; Hans Schäfer, Verfassungs- und Verwaltungsgerichtsbarkeit, in I STAATSBURGER UND STAATSGEWALT 159, I70 (Helmut R. Külz \& Richard Naumann eds., I963).

${ }^{3}$ See Rudolf Steinberg, Verwaltungsgerichtlicher Umweltschutz: Voraussetzungen und Reichweite der egoistischen Umweltschutzklage, II/12 UMWELT- UND PLANUNGSRECHT 350, 358 (I984). One partial exception occurs in planning law, because the Baugesetzbuch requires that public and private interests be balanced. See Baugesetzbuch [BauGB] § I(6), I986 BGBl. I 2253, 2254. Judicial review of the adequacy of this weighing process is possible. See Letter from Prof. Winfried Brohm, Faculty of Law, University of Konstanz, to Prof. Susan RoseAckerman, Yale Law School 2 (June 7, I993) (on file with the Harvard Law School Library).

${ }_{94}$ See supra p. 1288.

95 Actions challenging the constitutionality of a state or federal law, or challenging the compatibility of state law with federal law, cannot be used to review legal regulations and are not available to private individuals or groups. Such cases can only be brought by state or federal governments or by one-third of the members of the Bundestag. See GG art. 93(I)(2). "Concrete norm-control" actions under GG art. IOO(I), which deals with inter-court referrals of constitutional questions, apply only to formal laws, not to regulations. See Ossenbühl, supra note 85 , at $422-23$. The administrative courts can invalidate Länder regulations (Rechtsvorschriften) through "norm-control" actions brought by individuals who have been damaged or who expect to be damaged. See Verwaltungsgerichtsordnung [VwGO] § 47, 1960 BGBl. I I7, 22; Ossenbühl, supra note 85 , at $422-23$. 
the licensing of particular nuclear plants, ${ }^{96}$ environmental activists and concerned neighbors brought their opposition before the courts. These cases, although seldom successful on the merits, did serve to delay projects and raise public concern. ${ }^{97}$

Local citizens' initiatives (Bürgerinitiativen) have helped to organize the concerned public. ${ }^{98}$ However, neither organized environmental groups nor Bürgerinitiativen can be plaintiffs unless they can demonstrate that their organization's rights have been violated. ${ }^{99}$ To meet this requirement and obtain standing, Bürgerinitiativen have purchased land near major projects - a practice upheld by the Federal Administrative Court. ${ }^{100}$

Outside of those Bürgerinitiativen that have been able to purchase nearby land, access to court is limited to neighbors of planned facilities and to residents of communities where nature protection plans will be

${ }^{96}$ For a series of case studies involving nuclear plants, see VON DER BITTSCHRIFT zUR PLATZBESETZUNG: KoNFLIKTE UM TECHNISCHE GrosSPROJEKTE, cited above in note 84 . Important projects often provoked demonstrations with tens of thousands of objectors. See Dieter Rucht, Wyhl: Der Aufbruch der Anti-Atomkraftbewegung, in VON DER BITTSCHRIFT ZUR PLATZBESETZUNG: KONFLIKTE UM TECHNISCHE GROSSPROJEKTE, supra note 84, at 128 , 149 .

97 See Jost Halfmann, Social Change and Political Mobilization in West Germany, in INdustry and Politics in West Germany: Toward the Third Republic 5I, 8I (Peter J. Katzenstein ed., I989); Eckard Rehbinder, The Role of Administrative Courts in West Germany 24 (I985) (unpublished manuscript, on file with the Harvard Law School Library) (stating that nuclear power cases "have seldom been successful on the merits in the first instance and never in the second and third instances"). For examples of how activists have used the courts, see Dorothy Nelkin \& Michael Pollak, The Atom Besieged i55-66 (1981); and Rucht, cited above in note 96 , at $136-37$.

98 Over time some of these groups have taken on a more permanent character. An umbrella organization, called the Bundesverband Bürgerinitiativen Umweltschutz (BBU), was founded in 1972. See Rucht, supra note 88 , at 355 .

${ }^{99}$ See Rehbinder, supra note 97, at I6-17; see also VwGO \& 42(2), I960 BGBl. I 17, 22 ("Unless otherwise determined by law, suit is admissible only if the plaintiff claims to be violated in his rights by the administrative act or its denial or omission."). It is not enough that the government's action be illegal. In addition the plaintiff must actually have been injured in a "subjective," or individual, right. See Hans Jarass, Drittschntz im Umweltrecht, in FESTSCHRIFT FUR RUDOLF LUKES 57, 58 (Herbert Leßmann, Bernhard Großfeld \& Lothar Vollmer eds., I989).

The only exceptions are very limited state law provisions concerning implementation of the Nature Protection Law, which permit groups to participate in some state and local planning processes. They do not, however, give those groups access to the judiciary. See NatSchG $\S 29$, I987 BGBl. I 889, 902-03. Ten of the German states permit nature protection groups to challenge their procedures in court. The Federal Administrative Court has upheld the constitutionality of such provisions, see Judgment of Dec. 18, 1987, 78 Entscheidungen des Bundesverwaltungsgerichts [BVerwGE] $347,353-56$, and even in the absence of such provisions, has allowed a nature protection group access to court to claim that it was not consulted at all, see Judgment of Oct. 3I, 1990, ro Neue Zeitschrift für Verwaltungsrecht [NVwZ] 162, 164-65.

100 See Rudolf Steinberg, Judicial Review of Environmentally-Related Administrative Decision-Making, II TEL AvIV U. STUD. L. 6I, 64 (1992). The Administrative Court has held that it is acceptable for organizations to obtain standing through the purchase of a small piece of property in the neighborhood of the challenged project. See Judgment of July 12, 1985, 72 BVerwGE 15,16 . 
implemented or plants built. ${ }^{101}$ Yet some projects, such as coal-fired and atomic power plants, produce geographically far-reaching harms. Others, such as conservation proposals, benefit nature lovers living far from the site but arouse opposition from nearby neighbors. Standing in such cases is all but impossible for those who live at a distance from the project. ${ }^{102}$ They must show that injury is likely - a difficult task for most potential plaintiffs. ${ }^{103}$ Although the administrative courts have not completely ruled out claims of long-distance harm, the damage one might suffer in a possible nuclear power plant accident is not sufficient for standing purposes. ${ }^{104} \mathrm{~A}$ high risk of injury to a few people may confer standing, but a small risk of injury to millions of people does not. ${ }^{105}$

Once granted standing, individuals can defend only their own particular interests, not public interests. ${ }^{106}$ Thus, an individual cannot threaten an entire project if the problem can be solved with specific protective measures or with the payment of compensation. ${ }^{107}$ Furthermore, if only neighbors have standing to challenge a project, a solution crafted by the courts may reflect only the concerns of the neighbors, whose rights are the only ones implicated under German law. For instance, a court might order the construction of highway embankments to limit noise or the payment of compensation for the purchase of soundproof windows - measures that will not satisfy those seeking preservation of the natural landscape. ${ }^{108}$

101 See Thomas A. Ormond, Environmental Group Actions in West Germany, in PaRTICIPATION AND Litigation Rights OF ENVIRONMENTAL AsSOCiations IN EUROPE 77, 82-83 (Martin Führ \& Gerhard Roller eds., x99r); Steinberg, supra note Ioo, at 63-6g.

102 See Steinberg, supra note 93, at 355-56. The courts have defined the neighborhood of a nuclear power station to be a zone of about 30 kilometers around the plant. See Ormond, supra note 101, at 82; see also Wolfgang Baumann, Betroffensein durch Großvorhaben: Überlegungen zum Rechtsschutz im Atomrecht (pt. I), 9 BAYERISCHE VERWALTUNGSBLÄTTER 257, 259-60 (I982) (reviewing the nuclear power cases up to I982).

103 In one case, an individual who lived 45 kilometers from a nuclear power plant argued that he should be treated as a neighbor subject to "other hazards" under the Air Pollution and Noise Control Act. See BImSchG \& 5(I), I974 BGBI. I 72I, 724. If he were judged a neighbor, he could claim a right to participate in the licensing hearing. See id. § Io, I974 BGBl. I, at 725. However, the Federal Administrative Court denied him standing to bring his complaint before the administrative courts. Although the court admitted that procedural failures could produce violations of constitutional rights, it judged the risk of an explosion, on which the claim was based, to be too small to justify standing. See Judgment of Oct. 22, 1982, 98 Deutsches Verwaltungsblatt [DVBI] $183,183-84$.

104 See Judgment of Jan. II, 1985, 70 BVerwGE 365, 368-71; Judgment of Dec. 22, 1980, 6I BVerwGE 256, 262-7I; see also Steinberg, supra note 100, at 66-67 (criticizing the reasoning of the latter case).

105 See Baumann, supra note 102, at 265.

${ }^{106}$ See Jarass, supra note 99, at 61-62.

107 See Peter Badura, Schutz Dritter durch Nebenbestimmungen einer Planfeststellung oder Genelmigung, in FESTSCHRIFT FÜ RUDOLF LUKES, supra note 99, at 3, 9-I4.

108 See Johann Bizer, Thomas Ormond \& Ulrike Riedel, Die Verbandsklage im NATURSCHUTZRECHT 28-29 (I990). 
Germany's administrative law system comes close to Justice Scalia's view of the ideal relationship between the courts and administrative agencies. ${ }^{109}$ Review of high-level actions is difficult because no statute sets the procedural parameters for ministry policymaking. Judicial review is not used to safeguard the democratic legitimacy of rulemaking. And even when the legality of a rule does come before the court, the judges do not evaluate the procedures used in crafting that rule.

2. Informal Agreements. - As a consequence of the anemic quality of judicial review, German executive-branch policymaking tends to lack formality and accountability. No judicially enforceable statute constrains administrative policymaking. As a result, informal promises by industry groups to meet certain standards are sometimes neither legally binding nor publicly known. ${ }^{110}$ Such practices are possible because the laws permit, but do not require, regulations or guidelines and set no deadlines for the issuance of formal standards. The use of informal agreements makes outside review, not only of the process, but also of the substantive standards, impossible.

To take a concrete case, the government has the legal power to issue regulations governing the content of detergents. ${ }^{111}$ On at least one occasion, the Minister approved measures laid down in a letter from four industry associations instead of issuing a legally binding regulation. The letter was published in a federal register only after career officials in the Ministry applied pressure. ${ }^{112}$ In its published form, the letter can be distinguished from a regular legal ordinance only by the absence of section signs. ${ }^{113}$ Similar informal agreements have been used to stop the use of volatile chlorinated hydrocarbons and to decrease the use of chlorofluorocarbons in spray cans. ${ }^{114}$ More recently, asbestos was regulated by means of an informal letter that has not been made public. ${ }^{115}$

Such practices are less common in the United States, because American statutes are much more likely to set deadlines and to re-

109 See supra pp. 1285-87.

110 See Rüdiger Breuer, Verhandlungslösungen aus der Sicht des deutschen Umweltschulzrechts, in I KONFLIKTBEWÄLTIGUNG DURCH VERHANDLUNGEN, supra note 23, at 23I, 2505I; Gerd Winter, Gesetzliche Anforderningen an Grenzwerte für Luftimmissionen, in GrENzWERTE: INTERDISZIPLINÄRE UNTERSUCHUNGEN ZU EINER RECHTSFIGUR DES UMWELT-, ARBEITS- UND LEBENSMITTELSCHUTZES I27, I40-4I (Gerd Winter ed., I986).

"11 See Gesetz über die Umweltverträglichkeit von Wasch- und Reinigungsmitteln [WRMG] $\S 9(2), 1987$ BGBl. I 875,878 .

112 Interview with Eberhard Bohne, Ministerialrat at the Ministry for the Environment, Nature Protection and Nuclear Safety, in Bonn (Feb. 19, 1992) (discussing this incident).

${ }^{113}$ See Verfahrensregelung zur Mitteilung der Angaben nach $\S 9$ Wasch- und Reinigungsmittelgesetz, 4I BAnz. (Beilage) No. 40a, at 3-IO (Feb. 25, 1989).

114 See Breuer, supra note 110 , at 250-51.

115 See Interview with Bohne, supra note 112 (discussing the policymaking process in the Federal Environmental Ministry). 
quire, rather than simply to permit, rules. ${ }^{116}$ Although agencies issue guidelines and circulars to aid implementation, such measures cannot legally take the place of rules. Private agreements between regulated industries and the government generally cannot be handled with the secrecy and lack of accountability that is possible in Germany.

Nevertheless, informal industry-agency procedures have been used in the United States under the pesticide law, ${ }^{117}$ and voluntary compliance programs have been proposed for substances that contribute to global warming. ${ }^{118}$ These practices raise concerns about effectiveness and democratic accountability. Less problematic is the provision in the I990 amendments to the Clean Air Act that encourages producers of air toxins to reduce their discharges "voluntarily" in advance of a formal, technology-based rule. Firms that reduce their discharges by $90 \%$ before the applicable rule is proposed are exempt from the rule for six years, provided they meet an alternative standard reflecting their initial reduction. ${ }^{119}$ This measure gives firms an incentive to act quickly despite the long lead time needed to produce rules. Because the early reduction program sets definite statutory guidelines for implementation, it provides a flexible solution without sacrificing democratic legitimacy, openness, or clarity.

\section{ConClusions}

An analysis of German administrative law and practice can help Americans decide whether they wish to move toward a system that restricts judicial review of agency policymaking processes. Given the necessity of delegation, and the rise in the use of private experts and informal procedures, the risks of unconstrained administrative power should be clear. The informal, undocumented, and poorly understood processes outlined above suggest the kinds of problems that can arise. The American bureaucracy, lacking Germany's close connection between executive and legislature, would have even more independent power than German authorities if not constrained by procedural limits. Judicial review of high-level policymaking processes provides a needed

\footnotetext{
116 See, e.g., 42 U.S.C. $\$ \S 7409(\mathrm{a})(\mathrm{I}), 74 \mathrm{II}(\mathrm{b})(\mathrm{I}), 74 \mathrm{I2}(\mathrm{b})(\mathrm{I})$ (1988) (requiring the EPA to publish air pollution regulations before certain prescribed dates).

117 See Environmental Defense Fund v. Costle, 63r F.2d 922, 924-25, 932-37 (1980) (describing the EPA's "Rebuttable Presumption Against Registration" proceeding), cert. denied, 449 U.S. in I2 (I98I); Christopher J. Bosso, Pesticides and Politics: The life Cycle of a PUBLIC ISSUE I94-97 (1987).

118 See John H. Cushman, Jr., Clinton Urging Voluntary Goals on Air Pollution, N.Y. Times, Oct. 19, I993, at A23; Margaret Kriz, Lukewarm, 25 NAT'L J. 2028, 2028 (I993).

$119 \mathrm{See} 42$ U.S.C. \& 7412(i)(5) (Supp. III r99r); Office of Pollution Prevention \& Toxics, U.S. Environmental Protection Agency, EPA's 33/5o Program, Fourti ProgRESS UPDATE I $\rightarrow$ (I993).
} 
check on agencies' tendency to ignore the democratic basis of their power.

Americans need to distinguish between relatively superficial problems, which stem from failures of management, financial resources, and bureaucratic competence, and more basic flaws in the structure of democratic government itself. Even if the current American review process is cumbersome and imperfect, it responds to a genuine problem. Bureaucratic processes that emphasize openness and reasoned decisionmaking help to justify the necessary delegation of policymaking to the executive. The courts can enhance the democratic legitimacy of the modern American state by ensuring that basic procedural conditions are met. Americans should not rush either to embrace consensual processes or to remove the courts from their role as monitors of democratic legitimacy. 